\title{
$\bigcirc$ Inspektoráty menšinových škol v meziválečném Československu
}

\section{Karel Řeháček ${ }^{2}$}

a Státní oblastní archiv v Plzni

rehacek@soaplzen.cz

Received 28 May 2021

Accepted 15 August 2021

Available online 31 December 2021

DOI 10.15240/tul/006/2021-2-004
Abstract Inspectorates of Minority

Schools in Interwar Czechoslovakia

Minority education after 1918 took a copletely different direction than it had before the establishment of Czechoslovakia. The new social reality, the new laws and the different approach to minority issues led to an equalization of minority (state national) schools with other schools, the removal of most of the obstacles to their establishment and, above all, the nationalization of the whole process

of establishing and maintaining these schools. This also led to the need to put these schools under the state supervision. In terms of their pedagogical activities and the organization of teaching, inspectorates for Czech, German and Polish minority schools were established. The paper deals with the implementation of inspectors' agendas, the performance of inspections, inspection districts and their transformations and the staffing of inspectorates in the interwar period.

Keywords Czechoslovakia, 1918-1939, minorities, education, school inspection

\section{Úvod}

Inspektoři menšinových škol byli jedním z fenoménů meziválečného československého školství. Stali se sice součástí stávající funkční sítě školních inspektorů, měli však výrazně specifické zaměření. Jednalo se totiž o inspektory zprvu menšinových, posléze státních národních škol, kteří prováděli dohled nad školami, zřizovanými a vydržovanými na základě speciální legislativy. Přestože byl vývoj školství v Československu v letech 1918-1939 nahlížen z mnoha úhlo̊ pohledu (Štverák, 1983; Somr, 1987) a odborného zpracování se již dostalo i problematice menšinového školství (Šimáně, 2019; Řeháček, 2019), úloha menšinových inspektorů nebyla doposud náležitě reflektována, zhodnocena a doceněna. Ke škodě věci, nebot' se v jejich případě jednalo o poměrně významnou roli: ve srovnání s ostatními inspektory národních škol totiž 
inspektoři těch menšinových vykazovali mnohem specifičtější úřední činnost, takže jejich vyčlenění do samostatné kategorie bylo účelné ne pouze z pohledu školského vývoje meziválečného Československa. Je proto smysluplné o nich jako o zvláštní kategorii státních zaměstnanců přemýšlet i jako o svébytném tématu historického výzkumu.

Analýza problematiky inspektorů menšinových škol v meziválečném Československu je proto hlavním cílem této studie. Ta se na základě primárního pramenného výzkumu snažila postihnout specifika jejich činnosti a zasadit jejich působení nejen do tehdejšího školského systému, ale zdůraznit rovněž jejich mimoškolní, osvětovou a národní práci. Právě těmito aspekty se menšinoví školní inspektoři nejvíce odlišovali od svých kolegů dohlížejících na ostatní národní školy. Studie se proto ve svých hlavních částech zaměřila na vývoj menšinových inspektorátů v Československu v letech 1918-1939, na specifika profesní identity menšinových inspektorů a na jejich hlavní aktivity, tedy na agendu vlastního dohledu na výuku a výchovu žáků a na činnosti, které byly v práci menšinových inspektorů specifické.

Pramenů k poznání činnosti menšinových inspektorů není mnoho a jsou poměrně úzce zaměřené. Jelikož se jednalo o inspektory menšinových (státních národních) škol, nachází se jejich agenda jednak v archivním fondu s názvem Ministerstvo školství Praha v péči Národního archivu, jednak tvoří písemnosti vzniklé z činnosti inspektorátů samostatné archivní fondy nacházející se v regionálních veřejných archivech. Dochovaná agenda menšinových inspektorátů je poměrně různorodá, podle celostátní evidence archiválií se dochovalo 18 archivních fondů s archiváliemi vzniklými z činnosti českých inspektorátů a jeden archivní fond inspektorátu německých menšinových škol, což nereprezentuje ani polovinu z inspektorátů menšinových škol z roku 1935, kdy jich existovalo celkově 29. Ani v případě nedochovaných písemností z činnosti inspektorátů však není nutné na výzkum rezignovat. Mnohé informace se dají získat kupř. z korespondence samotných škol či školských spolků podporujících národní školy, jako byly v Československu Ústřední matice školská (Špiritová, 1993, Řeháček, 2007), Deutscher

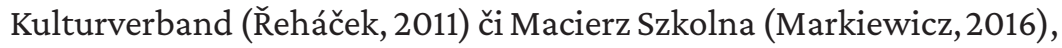
s inspektoráty a především pak ze školních kronik. 
Práce s výše uvedenými prameny vyžadovala kombinaci více metod historické práce. Základní metodou byla přímá interpretace relevantních primárních archivních zdrojů ve spojení s metodou induktivní. $\mathrm{V}$ části studie věnované vývoji menšinových inspektorátů byl využit diachronní přístup a progresivní metoda, spočívající ve sledování a zachycování historických událostí v časové souslednosti, naopak specifika profesní identity menšinových inspektorů a jejich hlavní aktivity byly sledovány problémově, a tak byl využit přístup synchronní. Výše uvedené základní metody byly doplňovány řadou dalších, hojně byly využity např. metoda komparativní a metoda sondy, které umožnily zevšeobecnění poznatků získaných studiem regionálních pramenů, $\mathrm{v}$ tomto případě západočeské provenience. Jejich generalizace v kombinaci se všemi uvedenými metodami umožnila vytvořit syntetický pohled na sledovanou problematiku, představit aktivity tohoto specifického segmentu školské správy meziválečného Československa, a přispět tak $\mathrm{k}$ lepšímu poznání menšinového života $\mathrm{v}$ jeho národnostně smíšených oblastech.

\section{Inspektoráty menšinových (státních národních) škol v Československu}

Po vzniku Československa nastaly v oblasti národního školství rozsáhlé a především z pohledu obyvatelstva české národnosti převážně pozitivní změny. Bezprostředně po převratu se do českých škol hlásilo mnoho dětí české i jiné národnosti, které do té doby $\mathrm{z}$ různých důvodů navštěvovaly cizojazyčné, zejména německé školy. Hlavní př́nos pro rozvoj českého národního školství po roce 1918 ovšem představovala nová školská legislativa, která umožňovala zakládání národních škol v národnostně smíšených oblastech za mnohem výhodnějších podmínek, než tomu bylo do té doby. Dne 3. dubna 1919 byl schválen zákon č. 189/1919 Sb., o školách národních a soukromých ústavech vyučovacích a vychovávacích v Čechách, na Moravě a ve Slezsku, podle poslance Národního shromáždění a starosty Ústřední matice školské (ÚMŠ) Jindřicha Metelky známý rovněž jako tzv. Metelkův zákon

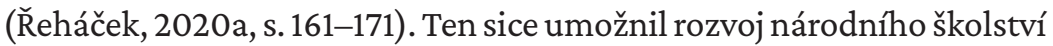


bez rozdílu vyučovacího jazyka, na české školství měl ovšem dopady nejpozitivnější (̌̌eháček, 2018, s. 219).

Podle zmíněného zákona mohla být zřízena veřejná menšinová škola v každé obci, kde žilo podle tř́letého (nikoliv již pětiletého, jak tomu bylo do té doby podle tzv. Hasnerova zákona z roku 1869) průměru nejméně 40 dětí školou povinných, ${ }^{1}$ ve výjimečných případech jich stačilo pouze 30, pokud v obci neexistovala veřejná škola s vyučovacím jazykem, který byl jejich jazykem mateřským. Zároveň bylo zákonem stanoveno, že při každé veřejné obecné škole mohla být za splnění určitých podmínek zřízena veřejná škola občanská (měštanská). Jelikož byly menšinové školy zřizovány Zemskou školní radou (ZŠR) a země navíc nově nesla veškeré osobní i věcné náklady na ně, nepodléhaly již místním ani okresním školním radám, takže obce a okresy nemohly jakkoliv vstupovat do procesu jejich zřizování. Odpadly tím nejen dosavadní časté obstrukce ze strany obecních zastupitelstev, ale také do té doby diskriminující a mnohdy ponižující výslechy rodičů a komi-

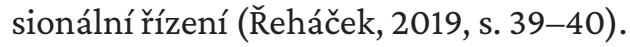

Na základě dalších zákonů, především zákona č. 292/1920 Sb., o školské správě, převzalo ministerstvo školství a národní osvěty (MŠANO) od 1. ledna 1920 nejen národní školy nově zřizované podle tzv. Metelkova zákona, ale také sít dosavadních menšinových škol, které byly zrrízeny již před jeho účinností. Došlo tedy k postátnění existujících soukromých českých škol a k zakládání nových národních škol, které byly i nadále oporou národního státu v národnostně expo-

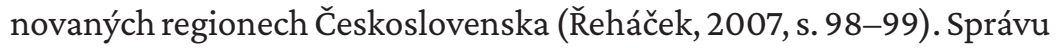
dosavadních menšinových či nově vznikajících národních škol vykonávaly okresní a místní školní výbory (OŠV, MŠV), zřízené rovněž podle výše uvedeného zákona (Topinka, 2008, s. 105-106). Ani poté však role národních školských spolků nezanikla, jelikož tzv. Metelkův zákon nevyřešil problémy národního školství beze zbytku a nedokázal zajistit možnost výuky v mateřském jazyce pro všechny žáky. A tak v místech, 
kde se nenašel zákonem požadovaný dostatek školou povinných dětí jedné národnostní skupiny, i nadále zajištovaly jejich vzdělávání soukromé školy. Těm však bylo již v okamžiku jejich zřízení automaticky přiznáváno právo veřejnosti, takže byly postaveny na roveň veřejným školám. Za stejných podmínek bylo uděleno právo veřejnosti i soukromým školám, které vznikly před vydáním tzv. Metelkova zákona, takže se téměř všechny soukromé obecné školy staly veřejnými a byly

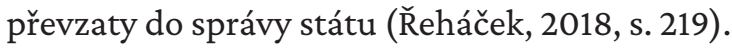

Přímý dohled nad školami vzniklými podle tzv. Metelkova zákona vykonávaly speciálně zřízené inspektoráty. Úplně první národní školy vzniklé na základě tohoto zákona však byly ještě podřízeny inspektorům veřejných národních škol bez ohledu na jejich vzdálenost od sídla inspektora, teprve následně byly dohledem nad menšinovými školami pověřovány nově zřizované inspektoráty národních škol s československým, německým a nakonec i polským vyučovacím jazykem. Kromě inspektorů mohli navštěvovat školy také delegáti již zmíněných národních školských spolků a další osoby, mj. zemští inspektoři státních národních škol či jiní úředníci MŠANO, často ovšem také politici a ostatní veřejně známé osobnosti.

Ve školním roce 1919/1920 byla zřízena první čtyři místa samostatných inspektorů menšinových škol v Liberci, Litoměřicích, Mostě a v Plzni a postupně došlo k vytvoření potřebné sítě inspektorátů. ${ }^{2}$ Co se týče českého národního školství, existovaly např. v roce 1928 jejich inspektoráty v Brně, Českých Budějovicích, Duchcově, Jihlavě, Karviné, Liberci, České Lípě, Litoměřicích, Olomouci, Opavě, Plzni, Podbořanech, Sušici, České Třebové, Trutnově, Karlových Varech, Znojmě a Žatci. ${ }^{3}$ Sít inspektorátů se rozrůstala, v roce 1935 jich bylo již 26 českých, 17 v Čechách a 9 na Moravě (Brno, České Budějovice, Duchcov, Hlučín, Jindřichův Hradec, Cheb, Jihlava, Karviná, Liberec, Česká Lípa, Litoměřice, Most, Olomouc, Opava, Plzeň, Podbořany, Sušice, Šumperk,

2 Záznam o jednání komise pro zhospodárněníveřejnésprávyz 2. 4. 1935. Kart. 309, Ministerstvo školství (MŠ) Praha. Národní archiv (NA).

3 Fascikl Menšinové školy, seznam inspektorátů státních národních škol s českým vyučovacím jazykem, 1928. Kart. 438. Ústřední matice školská (ÚMŠ) Praha. NA. 
Teplice-Šanov, Český Těšín, Česká Třebová, Trutnov, Ústí nad Labem, Karlovy Vary, Znojmo, Žatec), dva německé (Nový Jičín, Praha) a jeden polský (Fryštát/Karviná) a do roku 1938 jejich počty ještě nepatrně vzrostly, v roce 1936 vznikly např. inspektoráty českých státních národních škol v Horšovském Týně či v Novém Jičíně.

V souvislosti s důsledky hospodářské krize a nutností omezovat výdaje státu se zvažovalo jejich sloučení s inspektoráty ostatních veřejných národních škol. $\mathrm{V}$ tomto případě by byly menšinové inspektoráty zrušeny a dozor nad menšinovými školami měl převzít okresní školní inspektor národních veřejných škol. Na jednání komise pro zhospodárnění veřejné správy, které se konalo dne 2. dubna 1935 ve Strakově akademii, však viceprezident ZŠR v Praze Jaroslav Hendrych označil návrh za neproveditelný a argumentoval proti němu hlavně rozsáhlostí a rozmanitostí agendy menšinových inspektorů, ${ }^{4}$ jak bude ostatně potvrzeno i následující analýzou. K rušení inspektorátů tak nakonec nedošlo a inspektoři zůstali ve svých funkcích až do podzimu 1938. Po záboru části pohraničních oblastí Československa se mnohé inspektoráty stěhovaly, trutnovský kupř. do Hradce Králové (Kuba \& Lána, 2015,

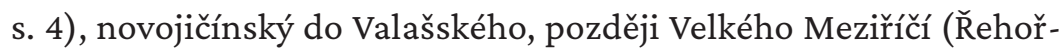
ková, 1959, s. 3).

\section{Profesní identita menšinových inspektorů}

Jestliže základem každé minority byly menšinové školy, patřili jejich učitelé k těm, kteří zdárný vývoj menšiny zásadním způsobem ovlivňovali, a to jak kvalitou výuky, tak národním uvědoměním a celkově charakterem jejich osobnosti. Menšinoví učitelé měli být př́kladem všem př́slušníkům dané národnostní skupiny a nad jejich odbornou i mravní kvalitou dohlíželi právě menšinoví inspektoři. $\mathrm{Z}$ toho plyne, že jejich odpovědnost za rozvoj menšiny byla ještě mnohem významnější, a i proto byly požadavky na ně nesrovnatelně přísnější.

4 Záznam ojednání komise pro zhospodárnění veřejnésprávyz 2. 4. 1935. Kart. 309, MŠ Praha. NA. 
Museli splňovat odborná, mravní i národní kritéria, museli být nejen profesními autoritami, ale také rádci, ochránci, mediátory či arbitry, jak vyplývá z jejich rozmanité, v následující kapitole uvedené agendy. $\mathrm{Z}$ odborného hlediska se jednalo o prověřené učitele se zkušenostmi se správou škol, mnozí prošli i pozicemi školních inspektorů, další před nastoupením místa menšinového inspektora absolvovali hospitační stáž na některém existujícím menšinovém inspektorátu. Př́ikladem je třeba ředitel měštanské školy ve Falknově nad Ohří František Věšín, který před nástupem na inspektorát do Podbořan hospitoval u svého pozdějšího kolegy v Karlových Varech Ludvíka Teyerleho.

Někteří inspektoři zůstávali v místě svého působiště celý profesní život, jak tomu bylo třeba $v$ př́padě plzeňského menšinového inspektora Antonína Follprechta, který v Plzni působil od roku 1919 do roku 1930, kdy byl penzionován. Jiní inspektoři naopak migrovali, již zmíněný František Věšín se kupř. z Podbořan, kde působil od srpna 1927, přemístil v lednu 1929 do nově zřízeného inspektorátu v Chebu, kde setrval do března 1936 , kdy z místa odešel. ${ }^{5}$ Dalším podobným případem byl i František Štolcpart. Dosavadní ředitel měštanské školy v Dobřanech byl 1. srpna 1926 jmenován nejprve menšinovým inspektorem v Sušici, počátkem října 1934 se přesunul do Plzně na místo penzionovaného Follprechta, ovšem od března do záŕí 1936 řídil po odchodu Věšína souběžně i menšinový inspektorát v Chebu.

Jak již bylo uvedeno, v případě inspektorů se jednalo o poměrně významná a národnostně exponovaná místa, tudíž se o jejich obsazování sváděl místy tuhý politický boj. To bylo na české straně dáno zejména tím, že o péči o českou menšinu v národnostně smíšených oblastech Československa soupeřily mnohé politické strany, ovšem největší rivalita panovala především mezi národními a sociálními demokraty. To se projevilo i na podzim 1933, kdy se v souvislosti s onemocněním plzeňského inspektora Ladislava Šebesty jednalo o jeho nástupci. Místo se obsazovalo konkurzem, což z celého procesu činilo politikum. Vedení

5 Školní kronika, s. 76. Česká obecná škola Tachov. Státní okresní archiv (SOkA), Tachov. 
plzeňské národní demokracie bylo znepokojeno zvěstmi, že místo má být obsazeno sociálním demokratem, bud' odborným učitelem Zahradníkem, kterého podporoval plzeňský sociálnědemokratický starosta Luděk Pik, nebo profesorem plzeňského učitelského ústavu Josefem Nesnídalem, za nímž stál sociálnědemokratický senátor Vojta Beneš. Národní demokraté naopak chtěli do funkce prosadit dosavadního sušického inspektora a svého spolustraníka Štolcparta. Předseda plzeňské organizace národní demokracie a náměstek plzeňského starosty JUDr. Matouš Mandl se proto koncem srpna 1933 obrátil na svého stranického kolegu, plzeňského senátora Eduarda Šimka, se žádostí o intervenci na různých místech v Praze. ${ }^{6}$ Šimek ve prospěch Štolcparta skutečně intervenoval a prostřednictvím ministra obchodu Josefa Matouška se podařilo dosáhnout Štolcpartova jmenování. ${ }^{7}$

Profesní záběr menšinových inspektorů byl poměrně obsáhlý, obdobně rozlehlé měli inspektoři také své úřední obvody. Ty se s růstem počtu státních národních škol průběžně měnily, většinou rozdělovaly. Analogicky s dělením obvodů a vznikem nových inspektorátů docházelo $\mathrm{k}$ přechodům celých okresů mezi inspektoráty a přechody se týkaly i jednotlivých škol. Př́́kladem budiž třeba situace v Pavlově Studenci na Tachovsku - do 31. prosince 1928 patřila tamní obecná škola do obvodu plzeňského inspektorátu, od 1. ledna 1929 spadala pod chebský inspektorát a v zárí 1936 přešla do správy nově zřízeného inspektorátu v Horšovském Týně (Bízová, 2006, s. 3).

Je však pochopitelné, že na celou tuto agendu nebyli menšinoví inspektoři sami. K dispozici měli úřední personál, který se staral o administrativu inspektorátu, aby se mohl inspektor co nejvíce věnovat vlastní inspekční činnosti. Chebský inspektorát kupř. kromě vlastního inspektora zaměstnával tajemníka (nejprve dosavadního řídícího učitele v Citicích na Falknovsku Bohumila Pavla, po jeho přeložení do Plzně

6 Dopis M. Mandla E. Šimkovi z 26. 8. 1933. Šimek Eduard, inv. č. 13113, sign. 173/92. Archiv města Plzně (AMP).

7 Dopis J. Matouška E. Šimkovi z 11. 10. 1933. Šimek Eduard, inv. č. 13113, sign. 173/92. AMP. 
v roce 1936 odborného učitele v Chebu Otakara Peroutku) a kancelářskou sílu Marii Hajerovou z Plzně.

Bez zajímavosti není ani umístění inspektorátů, které sídlily bud' samostatně v pronajatých prostorách, nebo přímo v budovách škol. Kancelár̆ karlovarského inspektora se kupř. od října 1926 nacházela ve studentském internátu při gymnáziu v Rybáŕích, ${ }^{9}$ chebský inspektorát zpočátku sídlil v české škole v Chebu, ale kvưli nedostatku místností se již v dubnu 1929 přestěhoval do školní budovy ve Františkových Lázních, kde pak zůstal sedm a půl roku a odkud zpět do Chebu přesídlil až 30. listopadu 1936. Ve Františkových Lázních zabíral v prvním patře školní budovy šest místností (kanceláře, byt inspektora, pokoj tajemníka a pokoj kancelářské síly). Nakolik byl správce školy z inspektora trvale sídlícího přímo ve školní budově nadšený, však nelze z dostupných pramenů posoudit.

\section{Agenda menšinových školních inspektorů}

Úkoly inspektorů státních národních škol byly různorodé a rozhodně mnohem pestřejší, než tomu bylo u jejich kolegů „nemenšinových“. Kromě dohledu na podmínky výuky a její kvalitu bylo klíčovým rozdílem především angažování se ve prospěch národnostní menšiny, které ovšem tvořilo nemalou přidanou hodnotu jejich pưsobení.

\section{Školní inspekce}

Hlavní agendou menšinových inspektorů byly stejně jako v případě jejich „nemenšinových“ kolegů inspekce škol. Při nich inspektoři zjištovali zejména podmínky vyučování (tj. kvalitu školních budov, přeplněnost tříd, úroveň sociálního zařízení i dalších příslušenství školy) a kvalitu výuky z hlediska pedagogického, zejména soulad vykládaného učiva se schválenými plány výuky, používané metody vyučování a jejich reálné výsledky atd. Výstupem z této činnosti byly inspekční zprávy, jejichž předběžné závěry byly s učiteli projednány obvykle již

8 Kronika české obecné školy, s. 49. Obecná škola česká Františkovy Lázně. SOkA Cheb.

9 Oběžník 33/1926 z 2. 10. 1926. Inspektorát menšinových škol s čsl. jazykem vyučovacím Cheb, kart. 1, inv. č. 14. SOkA Cheb. 
téhož dne na inspekční konferenci. Je otázka, zda se dá v tomto směru plně důvěřovat kronikářským zápisům, ale podle většiny studovaných školních kronik měli z inspekcí učitelé radost. Ve školní kronice české obecné školy v Kozolupech na Stříbrsku o návštěvě plzeňského inspektora A. Follprechta ze 17. června 1920 např. stojí: „Byl to radostný den jak pro žactvo, tak pro učitelstvo, nebot̉ zde hodnotil vykonanou práci zkušený učitel a osvědčený menšináŕ. “" ${ }^{10}$ Ale snad tomu tak skutečně i bylo, což dokládají i slova z Českého deníku v souvislosti s odchodem inspektora Follprechta do výslužby v roce 1930. V článku mj. stojí: „K učitelstvu byl laskavý, spravedlivý, nestranný, učitelstvo ho mělo rádo. Nemělo nikdy strach z jeho inspekce, nýbrž na ni se vždy těšilo.“" ${ }^{11}$ Výše uvedená polemická poznámka však souvisí i se skutečností, že inspekce kontrolovala rovněž vedení školních kronik, takže učitelé měli k podobnému jednání jistou motivaci. Inspektoři totiž plnili i roli cenzorů a existují doklady o tom, že nejenže odmítali schválit předložené kronikářské zápisy, ale dokonce i docílili jejich následných oprav. ${ }^{12}$

Inspekce se konaly poměrně často, byly předem hlášené, ale i „přepadové“, inspektoři se „jejich“ školy snažili navštěvovat každý rok, což dokládají mj. četné zápisy ve školních kronikách. Inspekce byly obvykle celodenní, což s cestováním do mnohdy odlehlých oblastí nebylo nikterak snadné a nejspíš ani úplně př́ijemné. Dokládá to třeba dopravní nehoda, která se stala zemskému školnímu inspektorovi Františku Řezníčkovi z Prahy 10. června 1930 při odjezdu z inspekce české státní národní školy ve Františkových Lázních. Poblíž Hradiště u Chebu sjelo auto, kterým cestoval, do příkopu a Řezníček utrpěl vážné zranění nohy. ${ }^{13}$

10 Pamětníkniha národníškoly v Kozolupech, s. 27. Národní škola (NŠ) Kozolupy. SOkA Plzeň-sever se sídlem v Plasích.

11 Rozloučení s insp. A. Follprechtem. Český deník. Roč. XIX (66), č. 283, 14. 10. 1930, s. 2.

12 Pamětní kniha národníškoly v Kozolupech, s. 93. NŠ Kozolupy. SOkA Plzeň-sever se sídlem v Plasích.

Kronika české obecnéškoly, s. 56. Obecná škola česká Františkovy Lázně. SOkA Cheb. 


\section{Zakládání a rozšiřování sítě škol}

Důležitá byla však úloha inspektorů také v zakládání nových státních národních škol či v rozšiřování těch stávajících o další třídy nebo expozitury. Inspektoři vypomáhali zejména při sepisování školou povinných žáků či při nalézání vhodných školních prostor při komisionálních řízeních a radili správcům škol s organizací tohoto procesu. Nejobtížnějším tak bylo pro inspektory paradoxně zejména období letních prázdnin, kdy se veškeré tyto činnosti musely před zahájením školního roku vykonat. Během letních prázdnin v roce 1924 tak např. již zmiňovaný inspektor A. Follprecht založil neuvěřitelných 27 nových českých škol. ${ }^{14}$

A nebyla při tom nouze o dramatické okamžiky, zejména v období bezprostředně po vzniku Československa, což dokládá např. incident ze 17. října 1920, kdy měla být otevřena česká škola v Tachově. Plzeňskému menšinovému inspektorovi Follprechtovi se dostalo hned na nádraží „vřelého přivítáni““, ${ }^{15}$ takže musel z obav o svůj život Tachov okamžitě opustit a škola byla nakonec otevřena až 1. dubna 1921

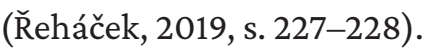

Inspektoři navrhovali rovněž vznik škol vyššího typu, zejména občanských (měštanských) a středních tak, aby bylo žákům menšinových škol v co největší míře umožněno i vyšší vzdělání v jejich rodném jazyce. Kromě toho se sami nejrůznějšími intervencemi aktivně snažili o zajištění co největšího počtu žáků škol v jejich obvodech a v metodách boje o žáky si byli podobní bez ohledu na národnostní charakter škol, které spravovali. A často museli bránit jim svěřené školy před útoky ze strany obyvatelstva jiné národnosti, které je vinilo z odnárodňování dětí a které zpochybňovalo smysl jejich existence. V meziválečném období se jednalo především o tzv. „čechizaci“ jinonárodních dětí, ovšem je nutno konstatovat, že mnohdy byla kritika odnárodňování oprávněná, jelikož nebyly výjimečné př́ípady, kdy např. českou

14 Rozloučení s insp. A. Follprechtem. Český deník. Roč. XIX (66), č. 283, 14. 10. 1930, s. 2.

15 Hlášení četnické stanice v Tachově Státnímu zastupitelstvív Chebu z 21.10. 1920. Kart. 104, Vr 2087/22. Krajský soud (KS) Cheb. Státní oblastní archiv (SOA) v Plzni. 
státní národní školu navštěvovaly děti maximálně z národnostně smí-

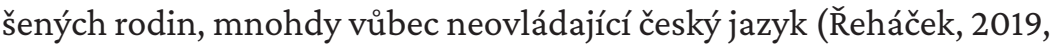
s. 221-224).

Ale v souvislosti s „přetahováním“ školních dětí si na české školy často stěžovali i sami Češi. Místní školní rada (MŠR) v České Kubici např. ve stížnosti na nově zřizovanou českou školu v Prenetu (Spálenci) na Domažlicku mj. uvedla, že „v ryze německé obci Prenetu, od České Kubice 3 kilometry vzdálené, má býti umožněno otevření české školy v Prenetu tím způsobem, že jsou někteří rodiče v České Kubici přemlouváni, aby své dítky posílali z České Kubice, kde mají veřejnou dvoutřídku, do menšinové školy v Prenetu“. ${ }^{16}$ Sušický menšinový inspektor Jan Hanuš celý prrípad vyšetřil, ovšem šetření uzavřel s tím, že se stížnost nezakládá na pravdě. Podle něj se v př́padě Prenetu jednalo o obec národnostně smíšenou, takže zřízení české školy v ní bylo oprávněné a rodiče se mohli svobodně rozhodnout, kam budou své děti posílat. Zároveň kritizoval počínání českokubického řídícího učitele a zároveň předsedy MŠR Bohumila Němečka, který podle jeho názoru svémocně zasahoval do jejich rozhodování, což bylo „zvláště v daném případě nedůstojno českého učitele, že se snažil klásti překážky zřízení nové školy české, takže se vlastně postavil proti důležitým zájmům národním, veřejným a státním“. ${ }^{17}$

Mediace sporů mezi příslušníky české menšiny

Další důležitá oblast činnosti inspektorů spočívala v hledání kompromisů v mnohdy složitých sporech mezi příslušníky české menšiny, jak je vidět napřn. na shora popsaném př́padu. Disharmonie ve vztazích mezi nimi se prakticky okamžitě projevovala i v chodu místní menšinové školy a mnohdy ji dokonce přímo ohrožovala na existenci. Inspektoři proto museli především úzce spolupracovat s MŠV, kam byli na čtyřleté období voleni rodiče dětí navštěvujících menšinové školy. Jejich zvolení zástupci skládali do rukou inspektora slib a byli jeho bezprostředními 
partnery v péči o jím dozorované školy. Zároveň však museli spolupracovat i se zástupci různých menšinových spolků, kteří však měli mnohdy poměrně dost odlišné pohledy na realitu, z čehož plynuly četné problémy.

Jedním z mnoha př́kladů je žákyně Božena Škabrounová z Pleše na Horšovskotýnsku. Plzeňský Český deník uveřejnil 16. října 1932 článek, v němž popisoval životní osudy její rodiny a žádal pro ni o sociální podporu. Reakce ze strany místních zástupců české menšiny na článek však nebyla nijak příznivá. MŠV v Eisendorfu (Železné) se proti tvrzením obsaženým v článku ostře ohradil a označil je za „úmyslný pokus klamati českou veřejnost “ ${ }^{18}$ O otci Boženy, Karlu Škabrounovi, se vyjádřil v dopise zaslaném Českému deníku takto: „Není pravdou, že jmenovaný trpí pro své uvědomělé češství od zdejších Němců. Jmenovaný jest holičem a chodí k němu výhradně jen Němci. Pan Škabroun po 14letém manželství nenaučil svoji ženu docela nic česky a prohlašuje, že ona toho nemá zapotřebí. Jsme rozhodně proti udělení podpor jmenovanému, nebot by se to dělo na úkor opravdu chudých a jistě českých lidí.“"19 Také řídící učitel české školy v Eisendorfu k tomu plzeňskému inspektoru státních národních škol F. Štolcpartovi napsal: „Pane inspektore, oznamuji Vám, že ten člověk toho nezasluhuje. Není též od Němců utiskován. To je veliká lež. Škabrounova činnost proti zdejší škole české jest prokázána a dá se vždy snadno dokázati.“20

Inspektoři řešili rovněž problémy mezi učiteli a dalšími zaměstnanci škol, obvykle opět v přímé souvislosti s rozhádanou menšinou. $V$ již zmiňovaném Tachově se napřr. místní odbor Národní jednoty pošumavské (NJP) snažil ovlivňovat obsazování učitelských míst a přemistování učitelů mnohdy až vyděračskými metodami. Inspektor menšinových národních škol v Chebu F. Věšín byl na nátlak tachovského odboru vyzván k provedení inspekce u řídícího učitele O. Peroutky a v dopise

18 Dopis $M \check{V} V$ v Eisendorfu ÚMŠ v Praze z 16. 10. 1932. Kart. 480, Eisendorf NA. ÚMŠ Praha.

19 Dopis $M \check{V} V v$ Eisendorfu Českému deníku z 16. 10. 1932. Kart. 6, ÚMŠ Plzeň. Pleš SOA v Plzni.

20 Dopis V. Řezáče F. Štolcpartovi z 25. 10. 1932. Kart. 6, Pleš ÚMŠ Plzeň. SOA v Plzni. 
NJP v Praze o tom mj. napsal: „Při vší úctě, kterou mám k činnosti odborů NJP, musím přece zdưrazniti, že zákroky jejich směřující k dislokačním opatřením nemají vždy jasnou motivaci. “21 Problémoví však byli i mnozí menšinoví učitelé, jejichž nemalá část se všemi prostředky snažila dostat na jiná místa v ryze českých oblastech, a tak není divu, že jejich fluktuace byla poměrně značná, což také neprospívalo harmonickému rozvoji české menšiny a kvalitnímu vzdělávání její nejmladší

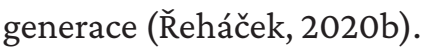

\section{Ochrana menšinových škol proti útokům zvenčí}

Útoky proti školám se však neomezovaly pouze na dobu jejich zakládání, jak bylo uvedeno v tachovském případě. Averze jinonárodní majority vưči menšinovým školám přetrvávala i nadále, $v$ čase se mnohde naopak ještě zvyšovala. Útoky, verbální i fyzické, zejména proti českým školám měly obvykle jediný cíl - všemi prostředky docílit snížení počtu žáků, a tím i jejich uzavření.

V př́ípadě českých menšinových škol na Plzeňsku se jednalo hlavně o aktivity německých nacionalistických stran. Správce české obecné školy v Černošíně na Stříbrsku Antonín Gruber v září 1933 inspektoru L. Šebestovi napsal: „Silná hakenkrajclerská akce, která se snaží zničiti jak českou školu obecnou, tak i mateřskou. Akce je silně podporována místním továrníkem F. Richtrem, který slíbil dětem místní německé mateřské školy, že sám na svůj náklad jim letos vypraví vánoční nadílku. “22 Ve druhé polovině třicátých let se nejistota projevovala v českých školách odlivem žáků, kteří se svými rodiči bud’ národnostně smíšené oblasti zcela opouštěli a stěhovali se do vnitrozemí Československa, nebo přecházeli do škol německých. Česká obecná škola v Caparticích na Domažlicku, která se již delší dobu potýkala s nedostatkem žáků, se v březnu 1938 musela vypořádat s dalším odchodem tří českých rodin. Horšovskotýnský inspektor Jan Čech sice pokládal tento úbytek za přechodný jev a vyjádřil naději, že „při uklidnění poměrů nastane opět

21 Dopis F. Věšína NJP v Praze z 21. 3. Kart. 61, sign. IV A 6931929. NJP Praha. SOAv Třeboni.

Dopis A. Grubera L. Šebestovi z 29. 9. 1933. Kart. 2, Černošín ÚMŠ Plzeň. SOA v Plzni. 
přírůstek dětí v české škole“, ${ }^{23}$ capartický řídící učitel však v dubnu $1938 \mathrm{v}$ dopise ÚMŠ zhodnotil důsledky odlivu žáků mnohem realističtěji, když napsal: „Správce školy oznamuje, že odstěhovaly se 3 rodiny z Capartic a tím ubylo zdejší škole 8 dětí, takže zdejší školu navštěvuje nyní 16 dětí. Ze jmenovaných rodin bylo by chodilo do mateřské školy 6 dětí, takže po tak velikém úbytku nelze zde založiti mateřské školy, proto správa školy navrhuje, aby přístavba školy nebyla v letošním roce provedena, neb na děti národnosti německé nelze se spolehnouti a českých by byl malý počet. “24

Rok 1938 byl již vůbec ve vývoji českého školství v národnostně smíšených oblastech maximálně nepř́íznivý. Národní školy a jejich učitelé sice zůstali až do poslední chvíle centry českého aktivismu, ovšem jejich existence byla stále obtížnější. Kromě všeobecně se zhoršující politické a v národnostně smíšených oblastech i bezpečnostní situace byly aktivity českých učitelů negativně ovlivňovány i „pragmatismem“ československé politické reprezentace ve vztahu k Německu. Na jedné straně tak byli čeští učitelé burcováni k pronárodním aktivitám, na straně druhé však kupř. plzeňský inspektor národních škol F. Štolcpart 23. srpna 1938 všechny školy ve svém správním obvodu „důvěrně a důtklivě“ upozornil na skutečnost, že „německá diplomatická intervence vyžádala si, aby žactvo bylo poučeno o tom, že nesmí zpívati hanlivé písničky a proslovovati hanlivá slova na Hitlera jako na hlavu státu“. ${ }^{25}$ I tohle přispívalo ke stále se prohlubující frustraci české menšiny a k sílícímu defétismu.

\section{Závěr}

Z výše uvedeného plyne, že úkoly inspektorů menšinových (státních národních) škol byly v meziválečném Československu skutečně výrazně

23 Dopis J. Čecha ÚMŠ v Praze z 27. 3. 1938. Kart. 475, Capartice ÚMŠ Praha. NA.

24 Dopis řídicího učitele školy v Caparticích ÚMŠv Praze z 26. 4. 1938. Kart. 475, Capartice ÚMŠ Praha. NA.

25 Zápisy o poradách učitelského sboru, 1920-1929, zápis z 1. 9. 1938. Obecná (národní) a měštanská (střední) škola Holýšov, zápisy o poradách učitelského sboru, 1920-1929, zápis z 1. 9. 1938. SOkA Domažlice se sídlem v Horšovském Týně. 
pestřejší a vrstevnatější než agenda jejich „nemenšinových“ kolegů. Kromě vlastního výchovně-vzdělávacího procesu měli totiž navíc na starosti i řadu aspektů souvisejících s elementární existencí národnostních menšin a jejich rozvojem. Další výzkum dané problematiky je možný především na regionální úrovni, která odráží mnohá specifika naznačená $\mathrm{v}$ této studii. Závěrem proto není bez zajímavosti publikovat informace o některých archivních fondech menšinových inspektorátů a jejich obsahu, aby si zájemce o tuto problematiku učinil obrázek o pestrosti dochovaného archivního dědictví. Kromě vlastních registratur inspektorátů (oběžníky, protokoly o inspekcích) totiž obsahují uvedené archivní fondy kupř. výroční statistické výkazy o stavu škol, osobní spisy učitelů i zaměstnanců menšinových škol, matriky škol včetně popisů budov s plánky a fotografiemi, dotazníky o mimoškolní činnosti učitelů a další písemnosti.

Zdaleka nejrozsáhlejším archivním fondem obsahujícím agendu menšinového inspektorátu je Inspektorát menšinových škol Liberec, který kromě vlastní registratury inspektorátu obsahuje třeba i osobní spisy učitelů i zaměstnanců menšinových škol. Ve fondu Inspektorát menšinových škol Most se nacházejí mj. matriky českých škol jeho úředního obvodu včetně popisů budov s plánky a fotografiemi, dotazníky o mimoškolní činnosti učitelů či matriky škol. Osobní spisy učitelů menšinových škol obsahuje rovněž fond Inspektorát menšinových škol s československým jazykem vyučovacím Ústí nad Labem, obsahem fondu Inspektorát státních škol národních Znojmo jsou třeba i stavební plány školních budov.

Na západě Čech je nejzachovalejším archivním fondem Inspektorát menšinových škol s československým jazykem vyučovacím Cheb, který obsahuje mj. matriky škol, seznamy školních dětí, záznamy o přidělení učebnic, odměny učitelům, agendu obsazování učitelských míst, inventář přírůstků, oběžníky inspektorátu, protokoly o inspekcích, osobní záležitosti učitelů, zprávy o stavu škol, výroční statistické výkazy o stavu škol, informace o stravovací akci či očkování dětí, učební osnovy a různé jiné oběžníky.

I z výše uvedeného výčtu je zřejmé, že má smysl se výzkumem této problematiky i nadále zabývat, ideálně na pozadí zkoumání menšinové 
problematiky a vývoje národního školství v národnostně smíšených oblastech meziválečného Československa.

\section{Primární zdroje}

Ministerstvo školství Praha, Národní archiv.

Ústřední matice školská Praha, Národní archiv.

Krajský soud Cheb, Státní oblastní archiv v Plzni.

Ústřední matice školská Plzeň, Státní oblastní archiv v Plzni.

Národní jednota pošumavská Praha, Státní oblastní archiv v Třeboni.

Obecná (národní) a měštanská (střední) škola Holýšov, Státní okresní archiv Domažlice se sídlem v Horšovském Týně.

Obecná škola česká Františkovy Lázně, Státní okresní archiv Cheb.

Inspektorát menšinových škol s čsl. jazykem vyučovacím Cheb, Státní okresní archiv Cheb.

Národní škola Kozolupy, Státní okresní archiv Plzeň-sever se sídlem v Plasích.

Česká obecná škola Tachov, Státní okresní archiv Tachov.

Šimek Eduard, Archiv města Plzně.

\section{Periodika}

Český deník.

\section{Literatura}

BÍZOVÁ, Dana, 2006. Obecná škola s československým jazykem vyučovacím Pavliov Studenec 1928-1938. Inventár Státního okresního archivu Tachov. Tachov.

KUBA, Jiří \& LÁNA, Tomáš, 2015. Inspektorát státnich škol národních s vyučovacím jazykem československým Trutnov (Hradec Králové) 1938-1940. Inventár Státního oblastního archivu v Zámrsku. Zámrsk.

MARKIEWICZ, Hanna, 2016. Rzecz o Polskiej Macierzy Szkolnej. Warszawa: Akademia Pedagogiki Specjalnej im. Marii Grzegorzewskiej. ISBN 978-83-64953-35-4.

ŘEHÁČEK, Karel, 2007. Ústřední matice školská v letech 1918-1951. In: Paginae historiae. Sborník Národního archivu 15. Praha: Národní archiv, s. 97-130. ISBN 978-80-86712-49-9.

ŘEHÁČEK, Karel, 2011. Deutscher Kulturverband v meziválečné Plzni. In: WASKOVÁ, Marie (ed.). Sbornik k poctě Evy a Karla Waskových, západočeských archivárư. Plzeň: Marie Wasková, s. 211-218. ISBN 978-80-254-9293-2. 
ŘEHÁČEK, Karel, 2018. České národní školství v letech 1918-1938. In: BÍLEK, Petr A., JIROUŠEK, Bohumil \& NOVOTNÝ, Lukáś (eds.). Československo 1918-1938/2018. České Budějovice: Jihočeská univerzita, s. 212-225. ISBN 978-80-73947-25-5.

ŘEHÁČEK, Karel, 2019. Jménem národa a pro národ. České školstvív národnostně smišených oblastech jihozápadu Čech v letech 1880-1945. Plzeň: viaCentrum. ISBN 978-80-87646-27-4.

ŘEHÁČEK, Karel, 2020a. Z periferie do centra? Rok 1919 ve vývoji českého menšinového školství. In: ŠVORC, Peter \& KOVAL', Peter. Rok 1919 a Československo. Postavenie a premeny periférii nového štátu v procese jeho konštituovania. Prešov: Prešovská univerzita. ISBN 978-80-555-1884-8.

ŘEHÁČEK, Karel, 2020b. Pozoruhodný životní přiběh menšinového učitele a básníka Vojtěcha Elhoty. In: Sborník Západočeského muzea v Plzni. Historie XX. Plzeň: Západočeské muzeum v Plzni. ISBN 978-80-7247-167-6.

ŘEHOŘKOVÁ, Marie, 1959. Inspektorát státních menšinových škol Nový Jičín 1924-1940. Prozatímni inventární seznam Státniho okresního archivu Nový Jičín. Nový Jičín.

SOMR, Miroslav a kol., 1987. Dějiny školství a pedagogiky. Praha: Státní pedagogické nakladatelství.

ŠIMÁNĚ, Michal, 2019. České menšinové školstvív Československé republice. Ke každodennosti obecných škol v politickém okresu Ústí nad Labem. Brno: Munipress. ISBN 978-80-210-9410-9.

ŠPIRITOVÁ, Alexandra, 1993. Ústřední matice školská v letech 1880-1919. In: Paginae historiae. Sbornik Státního ústředního archivu v Praze 1. Praha: Státní ústřední archiv v Praze, s. 178-195. ISBN 978-80-86712-49-9.

ŠTVERÁK, Vladimír, 1983. Stručné dějiny pedagogiky. Praha: Státní pedagogické nakladatelství.

TOPINKA, Jiří a kol., 2008. Př́íspěvek k pořádání školských fondů. Archivní časopis. 58, 2. Praha: Ministerstvo vnitra České republiky, s. 81-116. ISSN 0004-0398. 